\title{
Loess stratigraphy in Dutch and Belgian Limburg
}

\author{
ERIK P. M. MEIJs*)
}

Meijs, E. P. M. (2002): Loess stratigraphy in Dutch and Belgian Limburg. - Eiszeitalter und Gegenwart, 51: 115131; Hannover 2002.

Keywords: Loess stratigraphy, quaternary paleopedology, heavy mineral analysis, Belgium, Netherlands.

\begin{abstract}
Purpose of this paper is constructing a loessstratigraphical framework for a small region along the Albert Canal in Dutch and Belgian Limburg. Field observation and heavy mineral analysis are central focus of this study.

The large-scale sediment trap environment, at scarpe foots or between river-terraces led to the conservation of thick and differentiated loess sequences. The exposed walls of the widened Albert Canal, loess sections in the adjacent loess-exploitation zone and excavations at four major archeological sites did provide important data. By means of characteristic lithological and paleopedological "marker" horizons, mineralogical and chronological data and correlation with loess sections in Germany, a reliable loess-stratigraphical framework has been constructed. Beginning with the Holsteinian, it is matching marine/ice isotope records and terrestrial lacustrine pollen records. It contains four glacial loess cycles with five intercalated interglacial paleosols on top of the Rothem river terrace of the Maas.
\end{abstract}

\section{[Lössstratigraphie in Niederländisch und Belgisch Limburg]}

Kurzfassung: Ziel dieser Veröffentlichung ist es, für einen Abschnitt entlang des Albert Kanals in Niederländisch und Belgisch Limburg eine Übersicht zur Lössstratigraphie zu erstellen.

Die Arbeit gründet sich vor allem auf Feldaufnahmen und Schwermineralanalysen.

An Talhängen und zwischen Flussterrassen kam es zur Sedimentation und Erhaltung mächtiger, reich gegliederter Lössablagerungen.

Die Wände des Albert Kanals, Lössaufschlüsse im angrenzenden Gebiet und vier große archäologische Ausgrabungen wurden untersucht. Auf Grund von charakteristischen lithologischen und paläopedologischen Leithorizonten, mineralogischen und chronologischen Daten und deren Korrelation mit Lössaufschlüssen in Hessen wurde eine lössstratigraphische Übersicht für die Zeit seit dem Holstein-Interglazial erstellt, welche sich mit Ozean- und Eisisotopenabfolgen sowie mit

*)Anschrift des Verfassers: Drs. E. P. M. Meijs, Archeogeolab, Veulenerbank 33, NL-6213 JR Maastricht, The Netherlands. festländischen Pollenzonen korrelieren lassen. Es lassen sich vier glaziale Lösszyklen und fünf interglaziale Paläoböden auf der Rothem Terrasse der Maas ausmachen.

\section{Introduction}

Stratigraphical frameworks for loesses have had to be revised frequently over the past 40 years (see Haesaerts et al. 1981 and Juvigné et al. 1996). Because of the similarity of the sediments, sedimentological and cryogenic structures and paleosols originating from the different warm and cold stages of the Upper Pleistocene, few convincing stratigraphical "marker"-horizons can be detected. This is especially the case with regards to the pre-Weichselian loess-sediments, which until now, have been difficult to subdivide stratigraphically. In volcanic regions tephra layers can provide extensive lithostratigraphical markers. They often show a distinct mineral suite and are directly or indirectly dated by means of absolute dating methods.

Apart from ${ }^{14} \mathrm{C}$-dating on humic sediments, charcoal or molluscs, different forms of TL-dating have been developed over the past decades. However, for both of the last-mentioned dating methods many methodological problems still exist, especially in loesses, leading to different chronostratigraphical interpretations.

Since 1945 several researchers demonstrated the importance of heavy mineral analysis for lithostratigraphical studies on loess sediments.

Over the past years intensified investigations have taken place in new and enlarged quarries in the study area. The results of heavy mineral analysis, in combination with lithological, paleopedological and chronological data from the extreme long loess sequences along the widened Albert Canal and in adjacent loess-pits, give new insight into the loess stratigraphy of the study area.

\section{Research area}

The research area is shown in Fig. 1. It is located in a part of the drainage basin of the river Maas. Since the middle Pliocene (4 ma) the Maas met 
the Rhine near Aachen (Germany). Afterwards the Maas moved westwards and started around 800 $\mathrm{ka}$ to erode the Cretaceous and Paleocene limestones and Oligocene sands in the study area (VAN DEN BERG 1996). The continuous uplift of the area, the alternation of glacial and interglacial periods and the lateral westward shifting of the Maas were responsible for the preservation of an extraordinary extended and complete river terrace sequence. Transition periods between interglacial and glacial times were favourable for river-erosion and incision, while gravel-accumulation took place under cold and severe conditions, on the base of widely observed cryogenic features within the gravel beds
(VAN DEN BERG 1996). Interglacial regimes favoured the formation of river floodloams and lateral erosion. After the retreatment of the Maas from the research area, the preserved river terraces were alternately eroded by wind- and water-action and covered by eolian sands and loesses. The boundary between the coversand area in the north and the loess belt in the south is located near Gellik (Fig. 1). The present landscape is smoothly undulating, with SW-NE orientated valleys, draining to the rivers Jeker and Maas in the east.

Several brickyards are exploiting loess-pits near Kesselt and Veldwezelt (Nelissen pit "Kesselt" and Vandersanden pits "Veldwezelt-Hezerwater" and
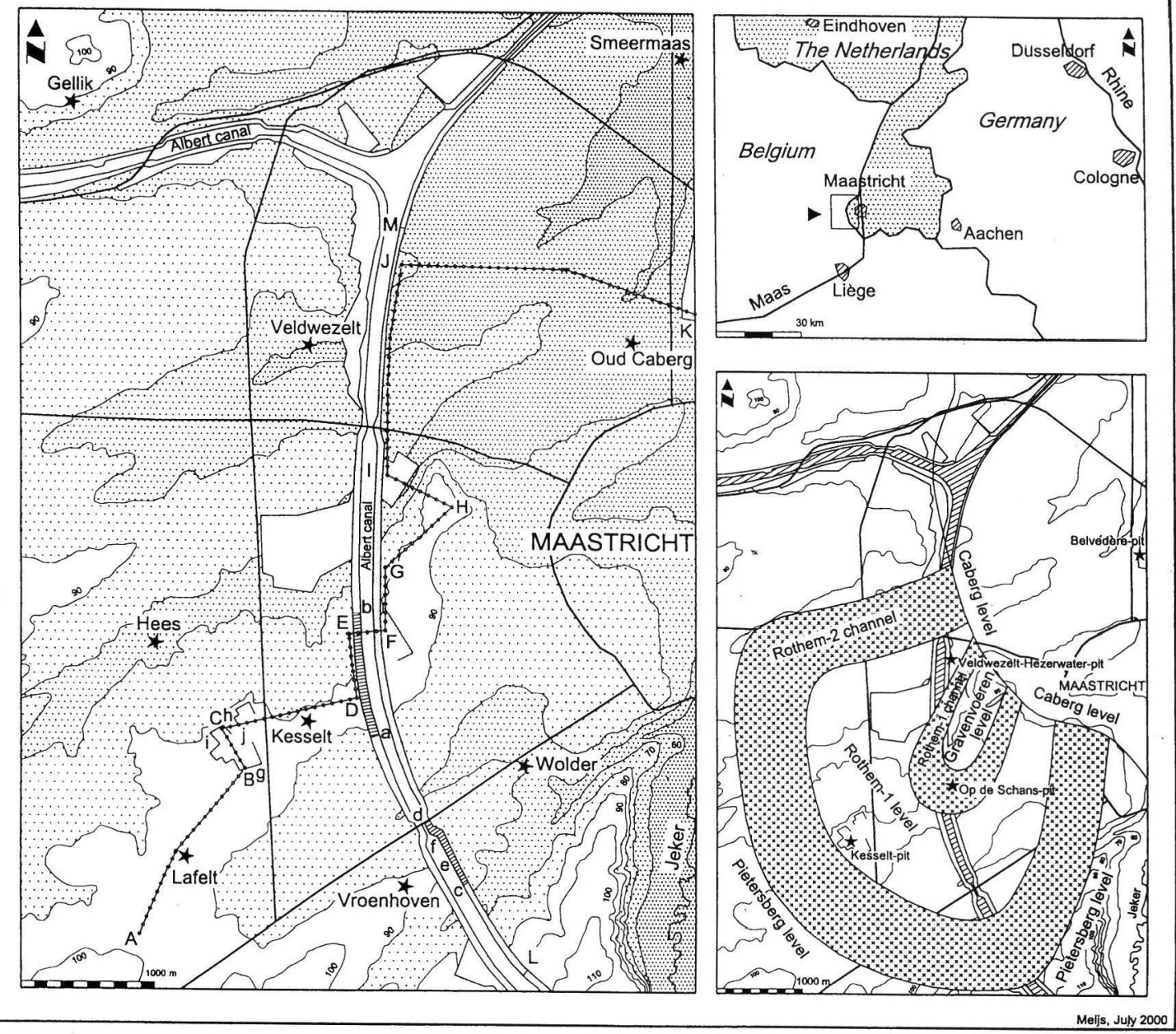

Fig. 1: Location of the study area and position of the cross sections L-M, A-K, a-b, d-c, f-e, g-h and i-j, which are shown in Fig. 2, 4, 5 and 6. At the right bottom: two fossil meander channel-beds from Rothem-1 and Rothem-2 river-terraces are indicated on the base of outcrop and drilling information.

Abb. 1: Lage des Forschungsgebietes und Lokalisierung der Aufschlüsse L-M, A-K, a-b, d-c, f-e, g-h und i-j in Fig. $2,4,5$ und 6. In der rechten unteren Ecke sind, basierend auf Bohrungen und Aufschlüssen, zwei fossile Mäanderbögen der Rothem-1 und Rothem-2 Flussterrasse wiedergegeben. 
"Op de Schans"). In fact the area along the Albert Canal is an important loess-exploitation zone which will be further investigated in the future.

The Nelissen pit "Kesselt" was, until 1996, the type-location for the so-called Hesbaye loess, which induced research by several universities. In the future this site will possibly be assigned as the type-location for the rare Upper Saalian "B-loess" (see chapter chronostratigraphy). The Vandersanden company started exploiting the loess-pit "Op de Schans" in March 2000 (Fig. 1). For the study of pre-Weichselian loesses, it is a promising location because it is situated in line with the most complete and differentiated pre-Weichselian outcrop along the widened Albert Canal (Fig. 2).

Between 1975 and 1985 the Albert Canal was widened and detailed research of the exposed walls led to a thorough understanding of the geological and geomorphological genesis of this area. Exposed sediments in neighbouring loess-pits were then correlated to the Albert Canal sequences.

The discovery of four major archeological sites (Maastricht-Belvédère, Kanne, Kesselt and Veldwezelt-Hezerwater) in the research area led to additional stratigraphical and chronological research. In conclusion, the research area could be considered as a key-region for present and future loessstratigraphical research.

\section{Terrace sequence of the river Maas}

In Fig. 2 the roughly SW-NE and S-N orientated cross-sections clearly show the strong influence of river erosion and aggradation processes in the area. The cross-section Lafelt-Oud Caberg (A-K; Fig. 2 bottom) is constructed on recorded sections along the Albert Canal and adjacent loess-pits and additional drilling information (HALET 1932, Felder \& Bosch 1989 and Geolab 1996), while the Vroenhoven-Veldwezelt cross-section (L-M; Fig. 2 top) is based on outcrop-information along the widened wall of the eastern side of the Albert Canal. Four distinct river terrace sequences can be distinguished. According to gravel-base heights the Rothem terrace-level seems to be divided into two sublevels; representing an outward sliding meandercurve-complex (Fig. 1). In a wider context, Felder \& Bosch (1989) deduced from the presence of different gravel-bases and two distinct floodloam generations, the existence of two Rothem sub-levels: Rothem-1 and Rothem-2. As well for the Gravenvoeren level, a distinction between Gravenvoeren 1 and 2 seems justified, although section $\mathrm{F}-\mathrm{H}$ in Fig. 2 is the only example of a terrace-division in the Gravenvoeren sequence throughout the Maas terrace area between Liège in Belgium and Roermond in The Netherlands (Felder \& Bosch 1989 and VAN Den Berg 1996). According to Felder \& BosCH (1989) the Pietersberg and Maarland terrace levels are present over a distance of 100 meters, in a SW direction from point $A$ and in a NE direction from point $K$ seen in the cross-section Lafelt-Oud Caberg, with gravel bases at about $98 \mathrm{~m}$ ASL and $38 \mathrm{~m}$ ASL (Fig. 1, Fig. 2).

It is clear that during long periods a sediment-trap existed between the heights of the Pietersberg and Gravenvoeren terraces, which resulted in an extremely thick loess cover in between.

\section{Heavy mineral analysis}

As stated above, lithological, sedimentological and paleopedological analyses of loesses are rarely able to discriminate between the different warm and cold stages of the Upper Pleistocene. However, correlations between different loess sections can be strengthened and stratigraphical conclusions can be drawn by means of heavy mineral analysis. In combination with micromorphological and lithological research, the content of the green amphibole and volcanic minerals are used to correlate individual loess sections and to construct a loess-stratigraphical framework for the research area.

Methods

Loess minerals:

The investigation of the mineralogical composition of the loess fraction $(30-63 \mu \mathrm{m})$ in relation to the loess stratigraphy began in The Netherlands (VAN DOORMAEL 1945). This research was continued by Gullentops (1954), Lautridou (1968), Juvigné $(1978,1985)$, Balescu \& HaEsaERTS (1984), Meijs (1985), Janus (1988) and Henze (1998) in the loess-belt of France, Belgium, The Netherlands and Germany. Juvigné (1978) proposed the ratio between "green amphibole + garnet / zircon + rutile" to distinguish Weichselian loess from pre-Weichselian loess. This approach was adopted in Germany by Henze (1998). Both GullenTOPS (1954) and MEIJs (1985) mentioned the importance of green amphibole as a discriminating heavy mineral in stratigraphical research. According to BALESCU et al. (1986) the West-European loess-belt is divided into separate regions with specific mineralogical properties. This implies that green amphibole percentages may differ slightly between these regions. The overall tendencies how- 


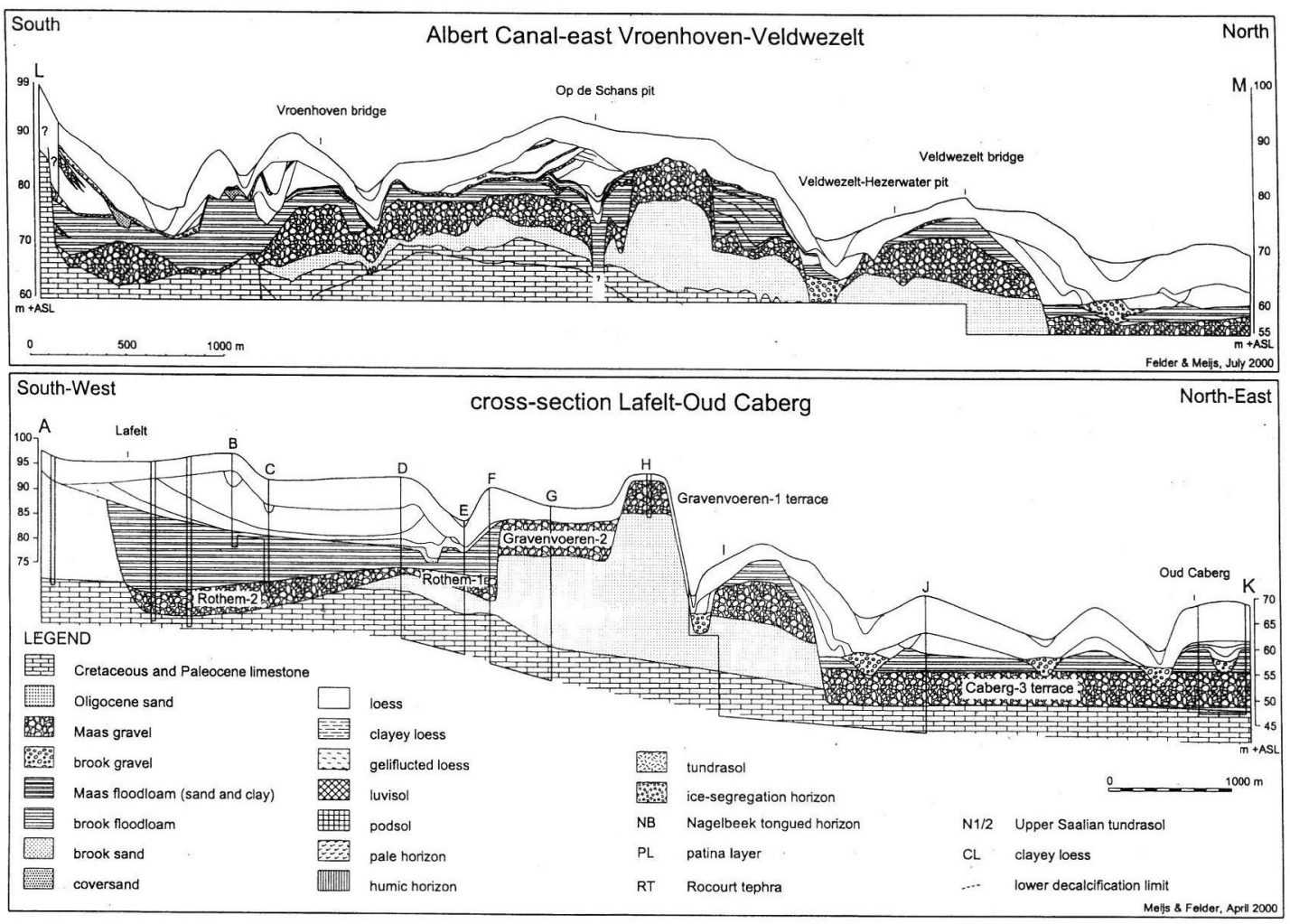

Fig. 2: SW-NE and S-N cross-section showing the geomorphological and geological structure of the study area. The role of fluvial/eolian erosion and aggradation processes are pointed out.

Abb. 2: SW-NO und S-N Querschnitte, welche die geomorphologische und geologische Struktur des Gebietes darstellen. Auffallend sind die Hinweise auf fluviatile und äolische Abtragungs- und Sedimentationsprozesse.

ever are the same. Even in northern Germany drilling data from Henningsen \& Stephan (2000) showed that the amount of green amphibole increases from the Elsterian to the younger Saalian and Weichselian sediment series.

Requivenient for this kind of stratigraphical research however, is that the samples should be of "real" eolian loess, as loess may have been redeposited and may be contaminated with older underlying material, mixing the green amphibole content.

Wet sieving of chemically untreated samples was carried out to obtain the fraction $30-63 \mathrm{~mm}$. The heavy and light minerals were separated in bromoform by using a centrifuge and the heavy mineral fraction was sucked up using a micropipet. From each sample about 300 transparent heavy minerals were counted, using the ribbon-counting method as described by vaN HARTEN (1965). The percentage of green amphibole in the frac- tion 30-63 $\mu \mathrm{m}$ was calculated based on the total amount of all counted transparent heavy minerals.

Volcanic minerals:

Until now only three volcanic tephra layers have been found in the research area, all originating in the volcanic Eifel in Germany.

Minerals from the Laacher See tephra have been detected on the archeological site of Kanne by Paulissen et al. (1981), just on top of the Holocene soil, that was burried by colluvium. The Laacher See tephra, 12,250 calibrated years BP, occurs in more than 50 pollen diagrams (Germany, Belgium, France and Italy) in the final phase of the Allerod oscillation (JuvIGNÉ 1993).

The Eltville tephra is the only tephra-layer visible by eye. It lies just beneath the Nagelbeek tongued horizon (NB) and is dated by ${ }^{14} \mathrm{C}$ and TL methods between 16 and $30 \mathrm{ka}$ (JUVIGNÉ 1993). 
Like the Laacher See tephra, the Rocourt tephra is only detectable by using microscopical equipment and occurs in secondary position in colluviated humic material, just above the Rocourt pedocomplex of the last interglacial (GuLLENTOPs 1954, Juvigné 1977, Mees \& MeIjs 1984). The estimated age on the base of indirect ${ }^{14} \mathrm{C}$ and ${ }^{230} \mathrm{Th}^{234} \mathrm{U}$ datings lies between 61.5 and $106 \mathrm{ka}$ (Juvigné 1993).

Stratigraphically the Eltville tephra is less interesting than the Rocourt tephra because the Nagelbeek tongued horizon (NB), which lies in the same stratigraphical position as the Eltville tephra, is a very characteristic and almost always present marker horizon from the French coast to eastern Europe (Haesaerts et al. 1981, Meijs et al. 1983).

For the mineralogical research of tephra-material, the sediment-fractions 63-106 $\mathrm{mm}$ (Laacher See tephra) and 106-300 mm (Rocourt tephra) were used. The further preparation and counting is similar to the above-mentioned methods used for the green amphibole analysis.

\section{Description and results}

In this chapter four major litho-pedological units are described separately; namely "A-loess", "Bloess", "C-loess" and "D-loess" (Fig. 3). From each unit samples were taken for heavy mineral and/or micromorphological analysis. The results are presented and discussed beneath.

Loess cycle A (max. thickness at location "Veldwezelt-Hezerwater": 24 meter)

In lower topographical positions and in shallow paleovalleys this sequence often starts with the presence of white-greyish (10YR5/4) pale sediment, followed by darkbrown (10YR4/3) humic material, most often directly covering the redbrown coloured (10YR5/8) Rocourt pedocomplex of the last interglacial. The material predominantly consists of redeposited loess-sediment, from the Rocourt pedocomplex (Juvigné 1978, VANDENBERGHE et al. 1998). The base of both horizons, especially that of the humic horizon, is of erosive origin (Fig. 5 bottom). The lower part is heavily bioturbated, leading to the formation of a mixed zone between the humic material and the pale sediment with numerous krotovinas. The humic horizon is often divided into three sublevels (MEES \& Meijs 1984, Haesaerts et al. 1999); the bottom and top consisting of dark brown material and the middle part of lightbrown material that may laterally merge in a downslope direction into a greyish pale horizon (Fig. 5 bottom). Just on top of this humic horizon a yellowish loess is sometimes present ("marker-loess"), representing the first eolian loess-supply since the last interglacial period.

Just after the outburst of the Eltville tephra, the climate was extremely cold and dry. As a result, a polar desert pavement (PL: patina layer) formed, discordantly lying upon the older deposits with windblown gravels at its base. The term "patina layer" has been chosen because of the clearly visible wind varnish (patina) present on the recovered paleolithic artefacts from this horizon. The wind erosion created a totally new landscape, disregarding the underlying valleys and ridges (Fig. 4 and 6). In fact it formed more or less the present landscape, because only a blanket of pure eolian loess was deposited on top of it afterwards, with no erosion phases in between (Brabant loess). The most important soil-formation phase which took place after the formation of the desert pavement resulted in the formation of the Nagelbeek tongued horizon (NB), lying just on top of the desert pavement and showing characteristic cryoturbation features at its base (HAESAERTS et al. 1981).

In general the underlying Eltville tephra is eroded during this wind erosion phase. Only in exceptional topographical positions, such as sedimenttraps, the tephra is preserved.

The present study and earlier studies (VAN DOORMAEL 1945, Gullentops 1954, Lautridou 1968 , Juvigné 1978, Balescu \& Haesaerts 1984, Meijs 1985, Janus 1988 and Henze 1998) reveal that the green amphibole percentages in Weichselian loess deposits range from 8 to $40 \%$. In the study area the mean percentage for the loesses deposited, just above the humic horizon, is around 10\%. Above these first loesses the percentage quickly reaches the mean values for the "A-loess" in this region, around 20\% (Fig. 5 middle part).

As seen before, volcanic minerals of the Rocourt tephra have been microscopically traced in the above-mentioned humic horizon. The minerals occur in secondary position throughout the humic material but often show a distinct concentration peak on top of the lower humic sublevel (Mees \& Meijs 1984, Meijs \& GroenendijK 1999, personal communication GuLLENTOPS 1999; Fig. 5 bottom).

Apart from the serrated appearance of the clinopyroxines, the presence of enstatite is very diagnostic for the Rocourt tephra (Gullentops 1954, Ju- 


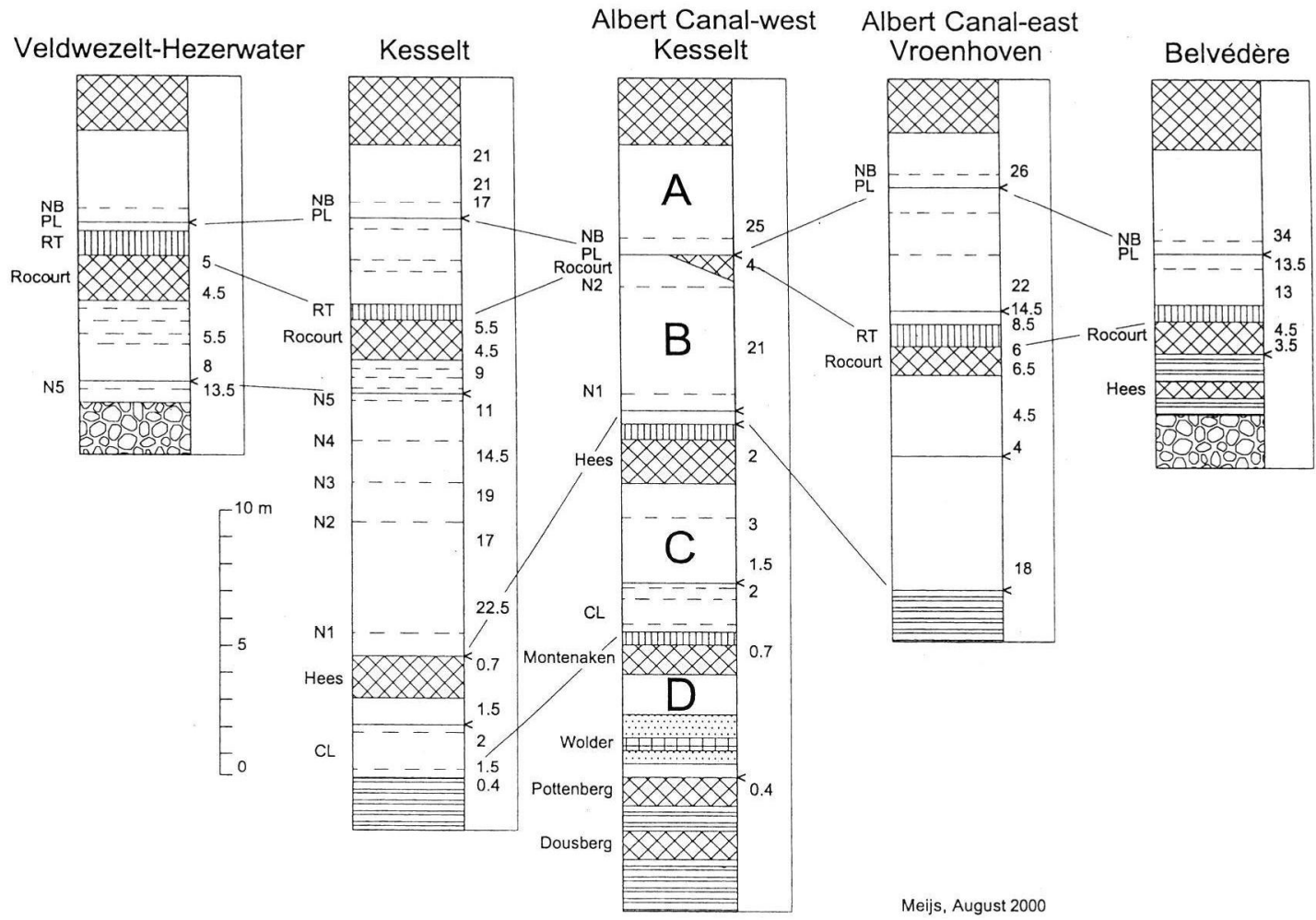

Fig. 3: Model, showing the proposed litho-pedological relations between the most important loess sections. The numbers are indicating the percentages of green amphibole from loess-samples in the fraction $30-63 \mu \mathrm{m}$. In this figure the tundrasols are indicated by dashed lines. For legend see Fig. 2.

Abb. 3: Sammelprofile für das Untersuchungsgebiet, welche die litho-pedologischen Zusammenhänge zwischen den wichtigsten Lössaufschlüssen andeuten. Die Zahlen geben den Anteil von grünen Amphibolen [in \%] am Schwermineralspektrum

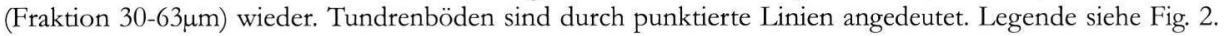

VIGNÉ 1977). Through microprobe analysis JUVIGNÉ et al. (1996) were able to detect the presence of volcanic glass shards in the heavy mineral section.

Recent mineralogical research reveals the presence of the Rocourt-tephra at three locations in the research area (Fig. 3, 5 and 6). Concentration values can decline dramatically in downslope as well in upslope directions in the same stratigraphical position (Fig. 5 bottom; see also Juvigné 1977). Fig. 5 shows that in extreme cases percentages are tending towards zero. The weakly developed humic horizon on the northern side of this section does not show any volcanic minerals at all.

Loess cycle B (max. thickness at location "Kesselt": 12 meter)

Thick loess sequences situated beneath the Rocourt pedocomplex are very rare. The relative abundance of these deposits in the research area is explained by the presence of geomorphologically defined sediment-traps between the different river terraces of the Maas. The most impressive "B-loess"-sequence is present in the Nelissen pit "Kesselt" which has been issue of studying by several universities during the past 50 years (Fig. 6). Here, even calcareous "B-loess" is found which has not been influenced by the soil-formation processes of the last interglacial. In the Nelissen pit, the so-called "B-loess" sequence has been interpreted as middle Weichselian from the first description of the section (GULLENTOPS 1954) until 1996. In 1996, the uncovering of the Rocourt pedocomplex and the presence of the Rocourt tephra on top of it allowed Juvigné et al. (1996) to put the "B-loess" sequence into the time before last glaciation (see also chapter chronostratigraphy). 
The "B-loess" sequence starts with a polar desert pavement, which in general is less pronounced than that of the "A-loess" and shows more features of water activity. Locally, the influence of running water is distinct, showing large and shallow gully systems. This wind and water erosion phase is responsable for an important hiatus in the different loess sections. The sequence on top of the desert pavement is representing an alternation of loesssedimentation and five tundrasol-formation phases (N1-N5). Fossil ice-wedge casts are present at three different levels, starting at about $10-20 \mathrm{~cm}$ above the paleo-surface of the middle three tundrasols (MeEs \& MeIJs 1984). The greyish (10YR5/3) tundrasols, especially the lower two, are well developed and have a characteristic appearance sometimes showing a whitish to greenish (10YR7/1) thin layer on top and a strong orange-like, rusty (10YR5/8) horizon at the base. They significantly differ from the over- and underlying tundrasols, present in the "A-loess" and "C-loess". The distance between the lower two tundrasols $(\mathrm{N} 1$ and N2) varies from 2 to 4 meters and occasionally a faint weak developed tundrasol is present between them (see also MeEs \& Meijs 1984 and Huijzer 1993).

An analogue loess sequence, situated below an Eemian paleosol and containing up to six tundrasols, has been reported by BiBus $(1974,1980)$ at several locations in Germany and is indicated as the "Bruchköbeler Nassboden-Komplex". Counting from below, the first and the third tundrasol have the most pregnant appearance. In comparison with the situation in the Nelissen pit "Kesselt" the similarity is striking, considering the fact that the second German tundrasol matches the occasionally appearing tundrasol of Kesselt (between the N1 and N2).

On top of this sequence the Rocourt pedocomplex is present at times, especially in sediment-traps like paleovalleys and scarp foots (Fig. 3, 5 and 6). Here periods of colluviation alternated with subsequent soil-formation finally produced a complex soil-profile showing several generations of clayilluviation, leaching and polygonal developement (Haesaerts \& Van Vliet-LanoË 1981, Mestdagh \& Haesaerts 1998, VAnmontFort et al. 1998, SCHIRMER 2000 and personal communication MÜCHER 1999). The issue of chronostratigraphical correlation with MIS- 3 instead of MIS- 5 will be discussed in the chapter dealing with chronostratigraphy.

The green amphibole percentages in the "B-loess" range from about $20 \%$ at its base to around $5 \%$ in the loess-sediments deposited at the end of this period, just prior to the onset of the last interglacial. In general the "B-loess" is heavily truncated. In such a situation only the lower amphibole-rich part is preserved from erosion and the overlying tundrasols and Rocourt pedocomplex are missing (Fig. 4). In that case distinction between "A-loess" and "B-loess" by means of their green amphibole content is not possible. Until 1984 loess sequences with high green amphibole percentages were assigned to the "A-loess". In the mid-eighties however Balescu \& HaEsaerts (1984) and Juvigné (1985) found in northern France and eastern Belgium an interglacial paleosol between loess layers with a high green amphibole content and it lasted until 1996 that JuviGNé et al. (1996) discovered the same situation for the sequence in the Nelissen pit "Kesselt" (see Fig. 6). Taking into account these new insights, the stratigraphical framework had to be revised and a great part of the so-called Hesbaye loess ("A-loess") was interpretated as "Bloess" (JUVIGNÉ et al. 1996).

The consequent decrease of the green amphibole content from the older to the younger layers is striking (Fig. 6). The decrease of these percentages towards the end of the "B-loess" period has also been reported in northern France and eastern Belgium by BALEscu \& HAEsAerts (1984) and Juvigné (1985). Juvigné (1985) suggests that the chemical weathering of green amphibole could provide an explanation. However, as shown in Fig. 6 green amphibole percentages already start to diminish within the calcareaous loess, which has not been influenced by chemical weathering processes at all. Thin section, grain-size and sedimentological analyses all point to an upward coarsening, a decrease in mineral sorting, a diminishing soil-stability and an increasing stream power regime in an upward direction within the "B-loess"sequence (Huijzer 1993, VANDENBERGHE et al. 1998). This implies that the climate was changing from dry towards more moist conditions. In accordance to the study area (Fig. 6) BiBus (1980) reported wide spread overlandflow activity in the above mentioned German loess sections, just above the sixth Bruchköbeler tundrasol, before the onset of the last interglacial. Thus climate change seems a more plausible explanation for decreasing amphibole percentages than chemical weathering.

As proposed by Juvigné (1978), the most probable provenance area for green amphibole is the outwash zone of the Scandinavian icecap. Possibly dry climatic conditions were a dominant fac- 


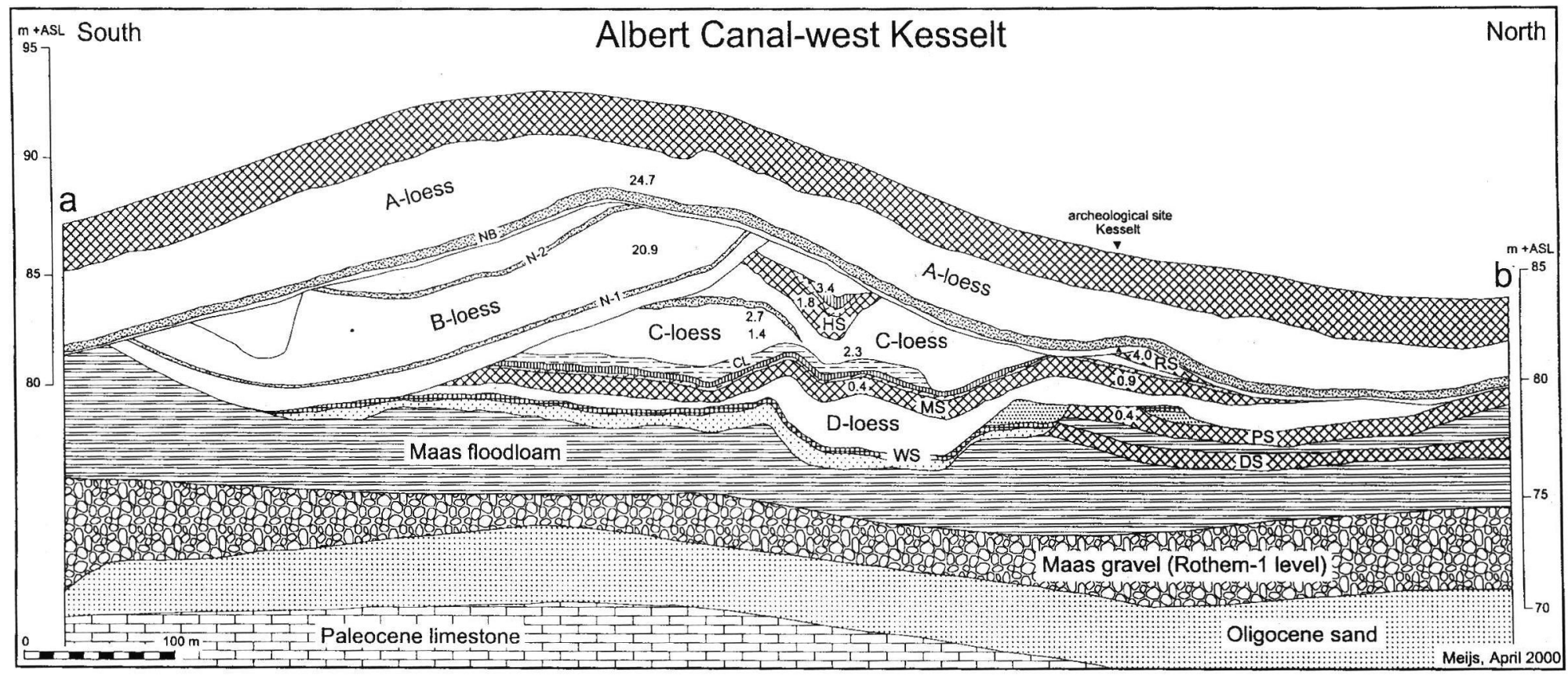

Fig. 4: Outcrop of the western side of the widened Albert Canal near Kesselt, showing a massive, almost complete loess sequence. Especially the glacial loess-covers of Middle and Lower Saalian age (C- and D-loess) and the interglacial luvisols from the marine isotope stages (MIS) 5, 7, 9, 11 and 13 are represented. The green amphibole percentages from different loess-samples in the fraction 30-63 $\mathrm{m}$ are indicated by numbers. The abbreviations RS, HS, MS, WS, PS and DS are respectively used for the Rocout soil, the Hees soil, the Montenaken soil, the Wolder soil, the Pottenberg soil and the Dousberg soil.

For legend see Fig. 2

Abb. 4: Aufschluss an der Westwand des Albert Kanals in der Nähe von Kesselt mit einer der vollständigsten Löss-Serien dieser Region. Besonders die glaziale Lössdecke der Mittel- und Alt-Saalezeit (C- und D-Löß) und die interglazialen Luvisols, die den Isotopenstadien (MIS) 5, 7, 9, 11 und 13 entsprechen, sind deutlich erkennbar. Die Abkürzungen RS, HS, MS, WS, PS und DS stehen für den Rocourt-Boden, den Hees-Boden, den Montenaken-Boden, den Wolder-Boden, den Pottenberg-Boden und den DousbergBoden. Die Zahlen geben den Anteil des Grünen Amphibols [in \%] am Schwermineralspektrum (Fraktion 30-63 $\mu \mathrm{m}$ ) wieder. Legende siehe Abb. 2. 

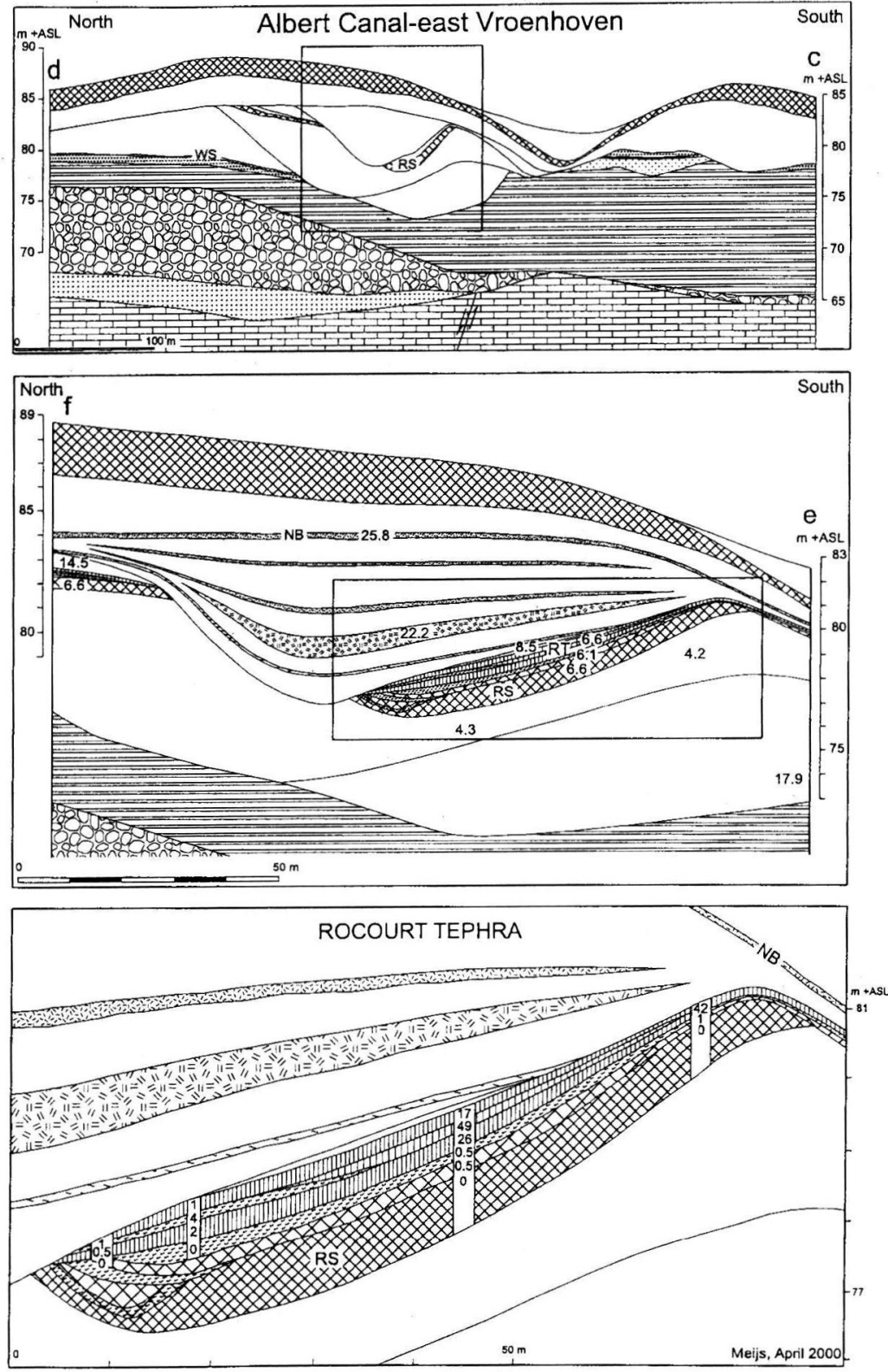

Fig. 5: Outcrop on the eastern side of the widened Albert Canal near Voenhoven showing a pedo- lithological sequence presenting the Weichselian (A-loess) and Upper Saalian (B-loess) periods. In the upper two drawings, the green amphibole percentages from the different loess-samples in the fraction 30-63 $\mu \mathrm{m}$ are indicated by numbers. The bottom drawing shows the variation in the volcanic mineral content of the Rocourt tephra. The numbers indicate the percentages of transparent, volcanic heavy minerals in relation to all counted transparent and opaque heavy minerals in the fraction 106-300 $\mu \mathrm{m}$. The abbreviation RS and WS are used for the Rocourt and Wolder paleosols. For legend see Fig. 2.

Abb. 5: Aufschluss entlang der Ostwand des Albert-Kanals, in der Nähe von Vroenhoven, mit einer Abfolge von Weichsel (A) und Jung-Saale (B). Die zwei oberen Zeichnungen geben den Anteil des Grünen Amphibols [in \%] am Schwermineralspektrum (Fraktion 30-63 $\mu \mathrm{m}$ ) wieder. Die detaillierte Zeichnung unten zeigt die Variation des Gehaltes vulkanischer Minerale des Rocourt -Tuffs. Die Zahlen repräsentieren den Anteil der transparenten vulkanischen Schwerminerale an allen gezählten transparenten und opaken Schwermineralen (Fraktion 106-300 $\mu \mathrm{m}$ ). Die Abkürzungen RS und WS bedeuten Rocourt-Boden und Wolder-Boden. Legende siehe Abb. 2. 

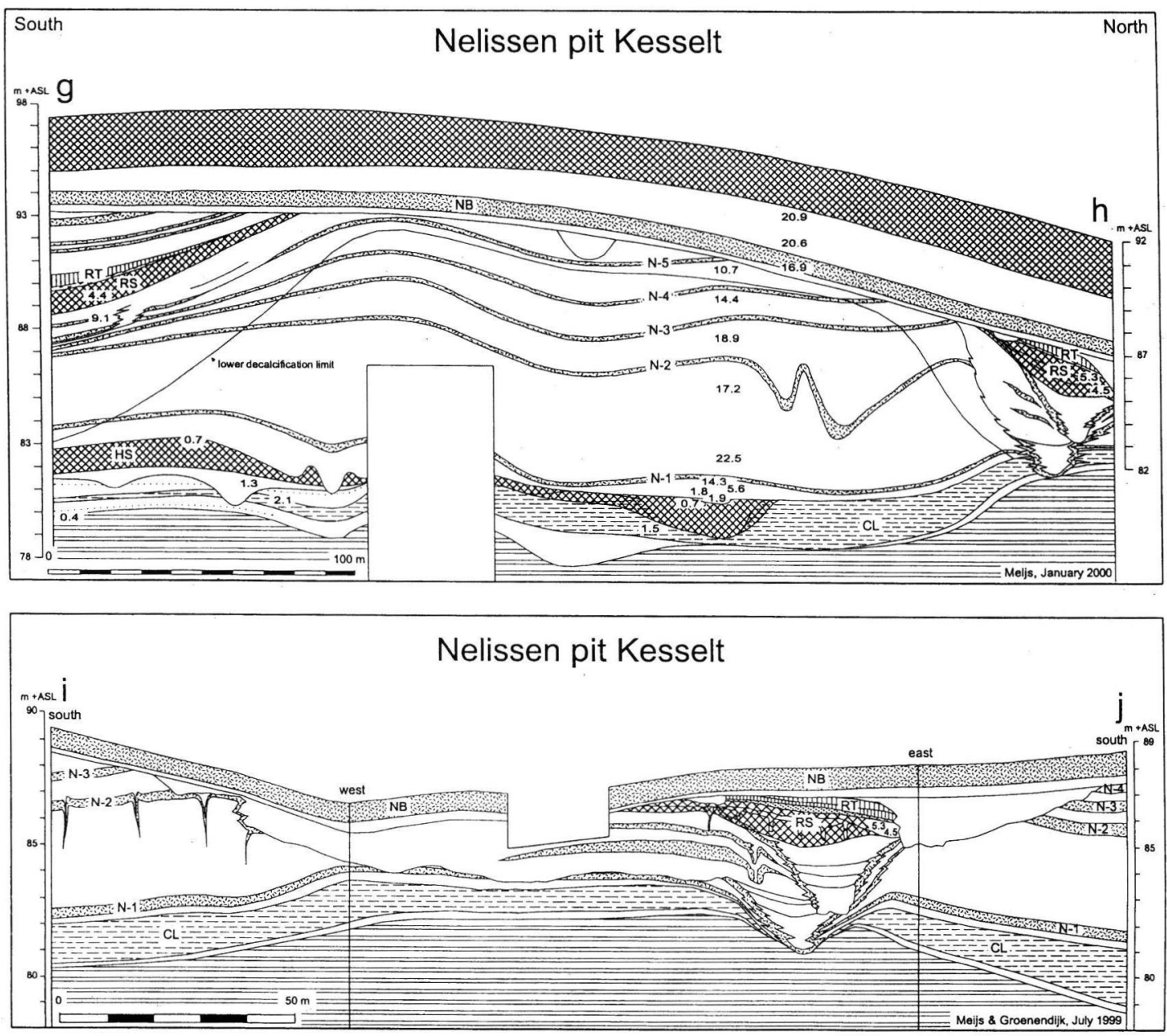

Fig. 6: S-N and W-E cross-sections in the Nelissan pit Kesselt showing the most complete Upper Saalian loess sequence (Bloess) in this region with at least five intercalated fossil tundrasols. The numbers are representing the green amphibole percentages from loess-samples in the fraction 30-63 $\mu \mathrm{m}$. The abbreviations RS and HS are used for the Rocourt and Hees paleosol. For the legend see Fig.2.

Abb. 6: S-N- und W-E-Querschnitte durch die Nelissen-Grube bei Kesselt (einer der Aufschlüsse mit der vollständigsten JungSaale-Lössabfolge (B) der Region), gekennzeichnet durch mindestens fünf fossile Tundrenböden. Die Zahlen geben den Anteil des Grünen Amphibols [in \%] am Schwermineralspektrum (Fraktion 30-63 $\mu \mathrm{m}$ ) wieder. Die Abkürzungen RS und HS stehen für den Rocourt-Boden und den Hees-Boden. Legende siehe Abb. 2.

tor in the transport of green amphibole to the research area. During moist to wet climatic conditions a long-lasting snow-cover probably prevented large-scale deflation from the braided outwash plains.

The uniformity of the green amphibole percentages in the upper part of the "B-loess" and within the Rocourt pedocomplex (4-6\%) in the different sections is striking (Fig. 3, 4, 5 and 6). This may mean that at the end of the "B-loess" period an uniform loess blanket was deposited, on which colluvial and soil-formation processes took place later on.

Loess cycle C (max. thickness at location "Albert Canal-west Kesselt": 7 meter)

Sediments of the "C-loess" sequence are encountered at two locations in the research area (near Kesselt; see Fig. 4 and 6).

The sequence starts with a characteristic clayey loess (CL). In most cases a weak greyish tundrasol is present at the base as well as on top of this 
clayey loess. Above, laminated and heavily cryoturbated loess-sediment occurs, which is overlain by more homogeneous loess with another tundrasol transferring upwards into laminated and geliflucted sediment (Fig. 4). The sequence ends with the formation of a red-brownish $(8.5 Y R 5 / 6)$ interglacial soil and overlying pale and humic horizons. Thin section analysis clearly shows the presence of in situ clay-cutans within the interglacial paleosol (MEES 1984). Micromorphological research also revealed that the overlying pale and humic horizons consist of eroded and colluviated material with a lot of transported and rounded ferric nodules derived from the interglacial paleosol below (MeEs 1984).

According to the mineralogical results presented in Fig. 3 and 4 and on the base of lithological and paleopedological characteristics of the over- and underlying sediments, this interglacial paleosol can no longer be correlated with the Rocourt pedocomplex. We therefore propose to name this paleosol after the neighbouring village of Hees in Belgian Limbourg; the Hees soil.

The green amphibole percentages in this sequence are rather constant, ranging from $1-3 \%$. In the Nelissen pit "Kesselt" (Fig. 6) it seems that the percentages here also decrease upthrough the stratigraphy. It may be possible that, given the more laminated and sandy character of the uppermost sediments, this is due to the mixing with older sediment-material from below.

Mineralogical research of the Hees soil and overlying pale and humic horizons in cross-section Albert Canal-west Kesselt (Fig. 4) did not reveal the presence of volcanic minerals.

Loess cycle D (max. thickness at location "Albert Canal-east Op de Schans": 8 meter)

In the research area this sequence represents the first eolian cycle after the formation of the wide spread and massive (sandy) floodloams belonging to the Rothem terrace-level of the river Maas. These sediments have been recognized at two locations along the widened Albert Canal (near Kesselt and Vroenhoven; Fig. 4 and 5).

The sequence starts with two different sediment facies. In the beginning, formation of broad, shallow gullys took place, filled up by redeposited sandy floodloam material.

Later, coversand was blown out of these gully systems onto adjacent interfluvia. Locally, a greyish (8.5YR5/3) podsolic soil is present on top of both facies, the so-called Wolder soil (FELDER \& BOSCH
1988). After the podsol-formation the sedimentation of coversand, continued in places (Fig. 4). Soon after however, loess-accumulation predominated. At their base the loesses have a laminated character, becoming more homogeneous, although periods of more overlandflow activity may intervene. The sequence is closed by a redbrown (10YR5/6-8) interglacial paleosol, with a subsequent grayish (10YR7/2 to $2.5 \mathrm{YR} 7 / 4)$ sandy, pale horizon and a darkbrown (10YR4/4) humic horizon. The interglacial paleosol is assigned as the Montenaken soil after FELDER \& BOSCH (1988) and thin section analysis revealed the presence of at least two clay-illuviation generations (MEEs 1984). The large number of charcoal pieces present in the pale horizon is striking. No micromorphological indications were found for an existing erosion hiatus between the Montenaken soil and the overlying pale and humic horizons. However, glauconite grains were found within the Montenaken soil, but not in the sediments above (MEEs 1984).

The percentages of green amphibole are very low $(0.5-1 \%)$ in this sequence and are difficult to discriminate between the sediments from below (Fig. 3 and 4).

The Montenaken soil and the overlying pale and humic horizons, were checked for the presence of volcanic minerals. Here also the result was negative.

\section{$\underline{\text { Rothem river terrace }}$}

As mentioned above the Rothem terrace is moulded in the study area as an outward bending meander-curve, with the deepest incision depth at the outerside of the curve (Fig. 1 and 2). During the process of lateral and vertical river erosion huge quantities of Oligocene sand were eroded and redeposited over short distances. The great sediment load probably lead to the accumulation of an important sequence of alternating clayey and sandy floodloams.

This sequence ended with the formation of an intense red-coloured (5YR5/8) interglacial paleosol, the so-called Pottenberg soil (FELDER \& Bosch 1988). In some sections of the widened Albert-canal another redbrown coloured luvisol is present beneath the Pottenberg soil, with intercalated floodloam in between (Fig. 2, 4). Probably local river activity of the "Caberg-1" Maas gave rise to a thin floodloam cover on top of this paleosol. It is representing the equivalent of the warm period between the formation of the Rothem-2 and Caberg- 1 terraces. The luvisol is assigned to 
the neighbouring Dousberg and will be named Dousberg soil (Fig. 4).

The earlier results of Bustamente Santa Cruz (1973), which show negligible green amphibole percentages for the Maas terrace sequences, can be supported by the present study, where the percentages range from $0-0.5 \%$ (Fig. 4,6 ).

\section{Chronostratigraphy}

By means of characteristic "marker" horizons, in combination with mineralogical and chronological data and in correlation with the "Bruchköbeler" loess sections in Germany (Bibus1974, 1980) it is attempted to construct an extended chronostratigraphical framework for the research area, which is related to the river terrace sequence of the Maas, the standard Marine Isotope Stages (MIS) of the astronomical calibrated ocean records ODP-677 and MD900963 (BASsINOT et al. 1994), the dust and temperature successions in the Vostok ice core (PEтtT et al. 1990,1999) and the long continental pollen records from Massif Central, France (REILLE et al. 1998) (Fig. 7).

In this respect the Vostok dust record is of major importance, indicating continental aridity, dust mobilization and dust transport were most prevalent in the full glacial stages. This is also reflected by many other dust records from for instance Greenland (GRIP MEMBERs 1993), Africa (DEMENOCAL 1995) and China (VANDENBERGHE et al. 1997). It is obvious that the extreme cold oscillations at the end of interglacial stages were too short to generate large-scale loess deflation (see also SCHIRMER 1999). Both the ice core sequence (PETIT et al. 1999) as well as the terrestrial pollen records (Tzedakis et al. 1997, Reille et al. 1998) confirm the presence of four major climatic cycles during the past 400,000 years. Each climatic cycle is starting with an extreme warm and humid stage (REILLE et al. 1998; MIS 11.3, 9.5, 7.5 and 5.5; Fig. 7) and ends with an extreme cold and dry stage (PETIT et al. 1999, BASSINOT et al. 1994, LOYER et al. 1995; MIS 10.2, 8.2, 6.2 and 2.2; Fig. 7).

\section{Weichselian}

For the Weichselian period, (MIS 2-4) recent multidisciplinary research at the archeological site VeldwezeltHezerwater is of great importance. Together with the standard sequences of Harmignies and Remicourt in Belgium (HAESAERTS 1974, HAESAERTS et al. 1999), this is one of the most complete Weichselian loess sequences in western Europe (GULLENTOPS et al. 1998). The present study focuses however on MIS-stages 512.

\section{Upper Saalian}

TL-dating of the "B-loess" sequence, containing the characteristic tundrasols beneath the (part of the) Rocourt pedocomplex with related Rocourt tephra, did provide mean ages of $130-140 \mathrm{ka}$ in the Nelissen pit "Kesselt" (VAN DEN HAUTE et al. 1998, WintLE in VAN DEN HAUTE et al. 1998). These ages are in accordance with mean TL-dating results of around $140 \mathrm{ka}$ from several loess sections in middle Germany, containing tundrasols of the "Bruchköbeler Nassboden-Komplex" present beneath a redbrown interglacial paleosol (ZÖLLER in FRECHEN 1991). At the archeological site Maastricht-Belvédère, TL-dating of the first eolian loesses, present above Caberg-3 floodloams and influenced by soil-formation processes of the last interglacial, gives a mean minimum age of $115 \mathrm{ka}$ (Debenham 1993). In fact, these results clearly demonstrate that the "B-loess", containing the characteristic tundrasols and showing green amphibole percentages from $20-5 \%$, perfectly fits into MIS-6 (Fig. 7).

However, loesses deposited during the period of strong overlandflow and gully-formation, just before the onset of the last interglacial period (see Nelissen pit "Kesselt", Fig. 6) yielded TL-ages of 50-60 ka (VAN Den Haute 1998, Wintle in VaN Den Haute 1998). On the base of these TL-ages VAn den haute et al. (1998) and Meijs \& GROENENDIJK (1999) assumed an important erosion hiatus between the gully-filling and underlying tundrasol-sequence N1-N5. In contrary to JUVIGNÉ et al. (1996), VANDENBERGHE et al. (1998) did not correlate the interglacial-like paleosol to the Rocourt pedocomplex (MIS-5). On the base of numerous ${ }^{14} \mathrm{C}$ - dates of the $\mathrm{N} 1-\mathrm{N} 5$ tundrasols $(30-37 \mathrm{ka})$ and the above mentioned TL-results of $50-60 \mathrm{ka}$ they proposed for correlation with MIS-3 and assigned it as the Lafelt soil.

According to new chronological data from a similar sequence at the archeological site VeldwezeltHezerwater, it seems reasonable to accept the correlation with MIS-5 after JuvigNé et al. (1996). A thorough study is prepared on this subject in cooperation with the universities of Gent (Belgium) and Amsterdam (The Netherlands). The chronological results from the archeological site Veldwezelt-Hezerwater will be published in a later paper.

\section{Middle Saalian}

TL-dating done on burnt flints and calcareous tufa and ESR-dating of molluscs, all found in relation to interglacial soil-formation on top of the Ca- 


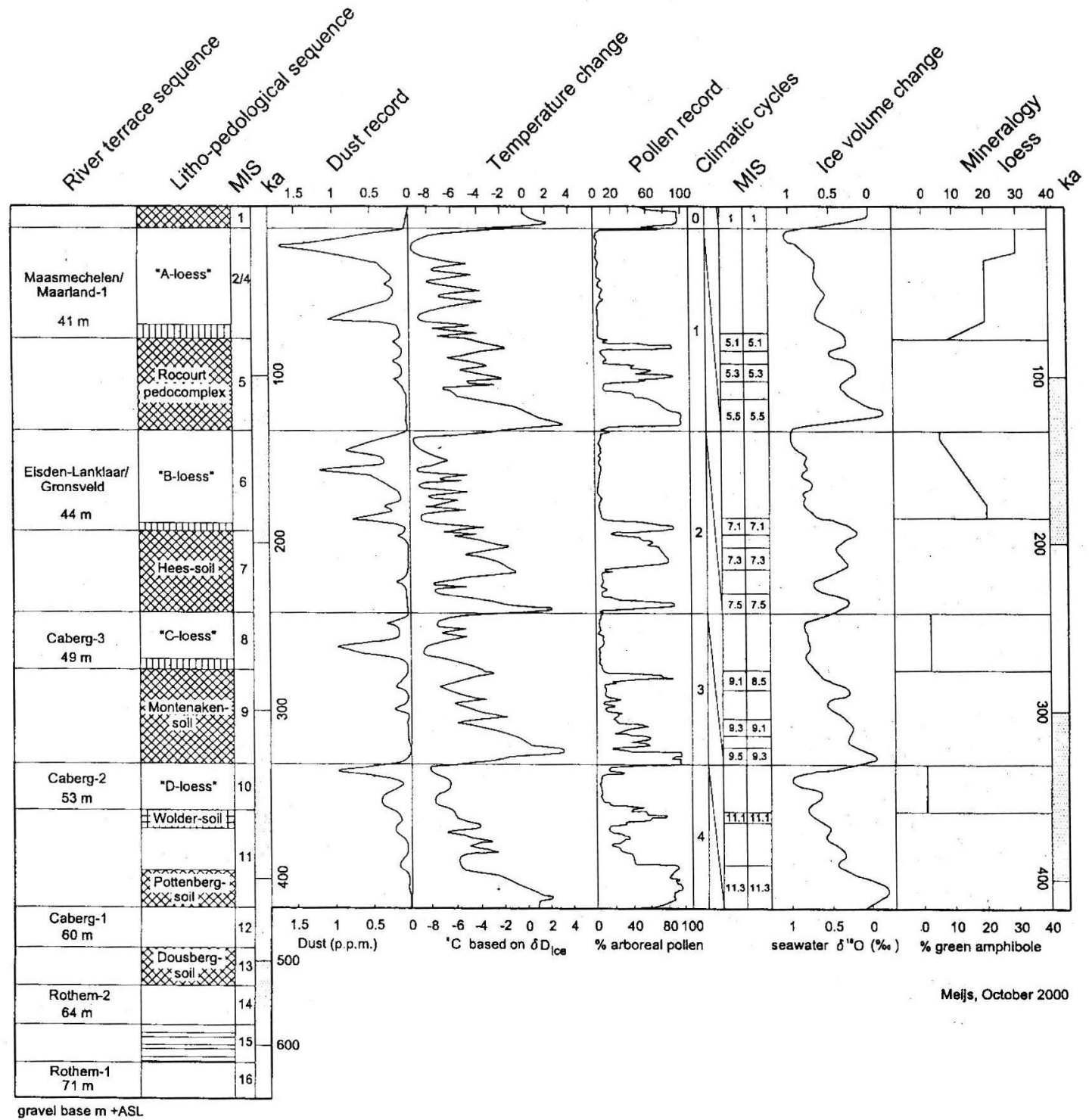

Fig. 7: Chronostratigraphical framework constructed by correlation of loess, river terrace, pollen, dust and marine/ice isotope sequences, on the base of lithological and paleopedological characteristics and mineralogical and chronological data. The dust and temperature records are adopted from PЕтT et al.(1999), while the pollen and ice-volume sequences are acquired from Reille et al. (1998) and BASSINOT et al. (1994).

For legend see Fig. 2.

Fig. 7: Chronostratigraphische Übersicht, entwickelt auf der Basis von Daten zur Lösssedimentation, Bildung von Flussterrassen, Staubabfolge, Pollenanalytik, Mineralogie und Chronologie. Staub- und Temperaturdaten nach PETTT et al. (1999), Pollendaten und Daten zum Eisvolumen nach ReiLle et al. (1998) und Bassinot et al. (1994). Legende siehe Abb. 2. 
berg-3 floodloams, show average ages ranging from $220 \mathrm{ka}$ (ESR) to $250 \mathrm{ka}$ (TL; with a minimum age of 175 ka for molluscs: vaN KolfsCHOTEN et al. 1993). According to mean TL-data of around $245 \mathrm{ka}$ for Middle Saalian loess sequences in middle Germany, present beneath two interglacial paleosols (ZOLLER et al. 1988) ${ }^{1}$ and the aboveindicated data for the archeological site MaastrichtBelvédère, it seems most logical to assign the gravel-aggradation phase of the Caberg-3 terrace level and the "C-loess" with green amphibole percentages ranging from 1-3\%, to MIS-8 (Fig. 7, see also van KOLFSCHOTEN et al. 1993).

This implies that the Hees soil matches with MIS7 and the Montenaken soil with MIS-9.

\section{Lower Saalian}

For correlating the Weichselian and Saalian river terraces with the marine/ice isotopic records and the terrestrial pollen sequences, only two convincing reference points are present: the Maasmechelen terrace (first presence of Rocourt tephra; PAUlissen 1973) and the Caberg-3 terrace (ESR and TL datings; see above). In downward direction only the Pietersberg-2 (800 ka), Geertruid-2 (1.1 ma) and Simpelveld-1 (2.1 ma) terrace levels form important fixing points by their paleomagnetical polarity and/or pollen content (VAN DEN Berg 1996). Recent studies by FeLDER \& BOSCH (1988, 1989), Juvigné \& Renard (1992) and van DEN BERG (1996) reported no further chronostratigraphical data that can support more detailed correlation. On the base of these fixing points and climo-tectonic modelling studies VAN DEN BERG (1996) found a correlation between the five lower river terraces of the Maas and the glacial marine isotopic stages $2 / 4,6,8,10$ and 12 , denoting that only long-lasting full glacial stages generate major river terrace systems (see Fig. 7). According to uranium series dating and biostratigraphical research Meijer and Preece (2000) discovered exactly the same situation for the lower terrace sequence of the river Thames in England. On the base of these two studies the strongly developed, reddish Pottenberg soil, which has been found in many sections along the widened Albert Canal on top of the Rothem-1, Rothem-2 and Caberg-1 floodloams, should be attributed to MIS-11. Recent chronometrical and pollen-stratigraphical research on lacustrine drilling cores in France, Italy and Greece and alluvial sediments in England, reveals strong evidence for assigning MIS-11 to the Holsteinian period (TzEDakIs et al. 1997, ReILLE et al. 1998 and Mejer and Preece 2000). In plac- es the Pottenberg soil is underlain by a redbrown luvisol (Dousberg soil), which represents the warm period (MIS-13) between the formation of the Rothem-2 and Caberg-1 river terraces (VAN DEN BERG 1996).

This implies that the "D-loess" correlates with MIS-10 and that the Pottenberg soil and Wolder soil are equivalent to respectively MIS-11.3 and MIS-11.1 (Fig. 7).

\section{Conclusions}

Thorough lithological, mineralogical and paleopedological examinations of numerous loess sections in the study area, the application of recent chronological data and extended correlation with loess sections in middle Germany, made it possible to construct a reliable loess-stratigraphical framework, which begins with the Holsteinian and matches with the marine/ice isotopic and terrestrial pollen records. It contains four glacial loess cycles with five intercalated interglacial paleosols on top of the Rothem river terrace of the Maas.

\section{Acknowledgements}

I wish to thank A. GroEnENDIJK for his full cooperation in the exhausting leveling and drawing sessions of the numerous loess sections in the field. He was very helpfull in discussing and interpretating the recorded data.

Prof. P. Van den Haute, Prof. J. Vandenberghe and Prof. E. Juvigné are thanked for providing constructive comments on the manuscript.

Appreciation goes out to prof. F. Gullentops, A. GROENENDIJK and J-P. DE WARRIMONT for their positive criticism and discussions in the field.

Great thanks are also due to W. FELDER and P. Bosch who supplied data from both sides of the widened Albert Canal, which was of emense value for this study.

Appreciation is extended to H. VANNIEUWENBORG of the company of Geolab for supplying drillingdata from the potential loess-exploitation zone between Kesselt and Lafelt.

Shawn Bubel, Frederic Classon and Elke SchlePUTZ were so kind to correct the English text. 


\section{References}

Antoine, P. [Ed.] (1998): Le Quaternaire de la vallée de la Somme et du littoral piccard. - Exc. Assoc. Franç. pour l'Étude du Quaternaire, 21-23 mai 1998, 162 S., 72 Abb.

Antoine, P., Lautridou, J., Sommé, J. et al. (1998): Les formations quaternaires de la France du Nord Ouest: Limités et corrélations. - Quaternaire, 9: 227-241, 3 Abb., 2 Tab., 1 Kte.; Paris.

Balescu, S. \& Haesaerts, P. (1984): The Sangatte raised beach and the age of the opening of the Strait of Dover. - Geologie en Mijnbouw, 63: 355-362; Utrecht.

- Dupuis, C. \& Quinif, Y. (1986): La thermoluminescence du quartz: un marqueur stratigraphique et paléogéographique des loess saaliens et weichséliens du NW de l'Europe. - C. R. Acad. Sc. Paris, 302 série II, (12): 779-784; Paris.

Bassinot, F. C., Labeyrie, L. D., Vincent, E., QuidelLEUR, X., Shackleton, N. J. \& LANCELOT, Y. (1994): The astronomical theory of climate and the age of the Brunhes-Matuyama magnetic reversal. - Earth and Planetary Science Letters, 126: 91-108; Amsterdam.

BERG, M. W. VAN DEN (1996): Fluvial sequences of the Maas: a $10 \mathrm{Ma}$ record of neotectonics and climate change at various time-scales. - Thesis University Wageningen: 181 p.; Wageningen.

BiBus, E. (1974): Abtragungs- und Bodenbildungsphasen im Risslöss. - Eiszeitalter und Gegenwart, 25: 166-182; Stuttgart.

- (1980): Zur Relief-, Boden- und Sedimententwicklung am unteren Mittelrhein. - Frankfurter Geowiss. Arb., D1: 295 p.; Frankfurt a. M.

Bustamante Santa Cruz, L. (1973): Les minéraux lourds des alluvions sableuses du bassin de la Meuse. - Diss. Katholieke Universiteit Leuven: 355 p.

Debenham, N. (1993): A short note on thermoluminescence data of sediments from the Palaeolithic site Maastricht-Belvédère. - Mededelingen Rijks Geologische Dienst, 47: 45-46.; Maastricht.

DOORMAEL, J. vAN (1945): Onderzoekingen betreffende de loessgronden van Zuid-Limburg. - Dissertatie Wageningen.

Felder, W. M. \& Bosch, P. W. (1988): Geologische kaart van Zuid-Limburg en omgeving: Oppervlaktekaart. - Rijks Geologische Dienst Heerlen.

- (1989): Geologische kaart van Zuid-Limburg en omgeving: Afzettingen van de Maas. - Rijks Geologische Dienst Heerlen.

FreCHEN, M. (1991): Thermolumineszenz-Datierungen an Lössen des Mittelrheingebiets. - Sonderveröffentlichungen Geol. Inst. Univ. Köln, 79: 137 p.; Köln.

GEOLAB (1996): Boringen ten behoeve van ontginningszone Kesselt voor Gewestplan Limburgs Maasland, gemeente Lanaken, kaartblad 34/2. Geolab b. v. b. a. Boringen-Bodemonderzoek, Plaanstraat 1, 9810 Eke-Nazareth, Belgium.
GRIP Members (Greenland Ice-core Project) (1993): Climate instability during the last interglacial period recorded in the GRIP ice core. - Nature, 364: 203-207; London.

Gullentops, F. (1954): Contributions à la chronologie du pleistocène et des formes du relief en Belgique. - Mémoires de l’Institut Géologique de l’Université de Louvain, 18: 125-166; Louvain.

- Groenendij, A. J., Meijs, E. P. M., Mücher, H. J., Vermeersch P. M. \& de Warrimont, J. P. (1998): Preliminary report of an exceptional palaeosol catena of the last interglacial in the loess area of Belgian Limburg near Veldwezelt. - The Eemian Excursion guide 1998, Local sequences, global perspectives: $35-39$.

HaEsaerTS, P. (1974): Séquence paléoclimatique du Pleistocène supérieur du bassin de la Haine (Belgique) Ann. Soc. Géol. Belg., 97: 105-139; Liege.

- \& Van Vliet-Lanoë, B. (1981): Phénomènes périglaciaires et sols fossiles observés à MaisièresCanal, à Harmignies et Rocourt. - Biuletyn Peryglacjalny, 28: 291-325; Wroclaw.

- Juvigné, E., Kuyl, O., Mǘcher, M. \& Roebroeks, W. (1981): Compte rendu de l'Excursion du 13 juin 1981, en Hesbaye et au Limbourg Neerlandais, consacrée à la chronostratigraphie des loess du Pleistocene Supérieur. - Ann. Soc. Géol. Belg., 104: 223240; Liege.

- Mestdagh, H. \& Bosquet, D. (1999): The sequence of Remicourt (Hesbaye, Belgium): New insights on the pedo- and chronostratigraphy of the Rocourt soil - Geologica Belgica, 2/3-4: 5-27; Brussels.

Halet, F. (1932): La Géologie du flanc occidental de la vallée de la Meuse à l'Ouest de l'enclave de Maastricht d'après les sondages d'étude du Canal Albert. - Bull. Soc. Belge Géol., 42: 195-225; Brussels.

HARTEN, D. van (1965): On the estimation of relative grain frequencies in heavy mineral slides. - Geologie en Mijnbouw, 44: 357-363; Utrecht.

Henningsen, D. \& Stephan, H.J. (2000): Die Schwermineral-Verteilung im Quartärprofil der Forschungsbohrung Tüschenbek (Schlewig-Holstein). - Eiszeitalter und Gegenwart, 50: 50-55; Hannover.

Henze, N. (1998): Kennzeichnung des Oberwürmlösses der Niederrheinischen Bucht. - Kölner Forum Geol. Paläontol., 1: 212 p.; Köln.

Huizer, A. S. (1993): Cryogenic microfabrics and macrostructures: Interrelations, processes and paleoenvironmental significance. - Thesis Vrije Universiteit Amsterdam: 245 p.

JANUS, U. (1988): Löss der südlichen Niederrheinischen Bucht - Kölner Geographische Arbeiten, 49: 174 p.; Köln.

JuvigNÉ, E. (1977): Zone de dispersion et age des poussieres volcaniques du tuf de Rocourt - Ann. Soc. Géol. Belg., 100: 13-22; Liege.

- (1978): Les minéraux denses transparents des loess de Belgique. - Zeitschrift für Geomorphologie, 22: 68-88; Berlin. 
- (1985): The use of heavy mineral suites for loess stratigraphy. - Geologie en Mijnbouw, 64: 333-336; Utrecht.

- (1993): Contribution à la tephrostratigraphie du quaternaire et son application a la géomorphologie. - Toelichtende Verhandelingen voor de Geologische en Mijnkaarten van België, 36: 66 p.; Brussels.

- \& Renard, F. (1992): Les terrasses de la Meuse de Liege a Maastricht. - Ann. Soc. Géol. Belg., 115, (1): 167-186; Liege.

- Haesaerts, P., Mestdagh, H., Pissart, A., \& BaLESCU, S. (1996): Révision du stratotype loessique de Kesselt (Limbourg, Belgique). - C. R. Acad. Sci. Paris, 323: 801-807; Paris.

Lautridou, J. P. (1968): Les loess de Saint-Romain et de Mesnil-Esnard (Pays de Caux). - Bull. C. Géomorph., 2: 56 p.

Kolfschoten, T. van, Roebroeks, W. \& VandenBERGHE, J. (1993): The Middle and Late Pleistocene sequence at Maastricht-Belvédère: the Type Locality of the Belvédère Interglacial. - Mededelingen Rijks Geologische Dienst, 47: 81-91; Maastricht.

Loyer, S., Van Vliet-Lanoe, B., Monnier, J-L., HalLegouet, B. \& Mercier, N. (1995): La coupe de Nantois (Baie de Saint-Brieuc, France): Datations par thermoluminescence (TL) et données paleoenvironnementales nouvelles pour te Pleistocène de Brétagne. - Quaternaire, 6 (1): 21-33; Paris.

Mees, R. P. R. (1984): Paleobodems in de löss in Westen Midden-Europa. - Doctoraal scriptie, Instituut voor Bodemkunde, Rijksuniversiteit Utrecht: $72 \mathrm{p}$.

- \& Meijs, E. P. M. (1984): Note on the presence of pre-Weichselian loess deposits along the Albert Canal near Kesselt and Vroenhoven (Belgian Limbourg). - Geologie en Mijnbouw, 63: 7-11; Utrecht.

Mejjer, T. \& Preece, R. C. (2000): A review of the occurence of Corbicula in the Pleistocene of NorthWest Europe. - Geologie en Mijnbouw / Netherlands Journal of Geosciences, 79 (2/3): 241-255; Utrecht.

MeIJs, E. P. M. (1985): Loess stratigraphical research at the paleolithic site Maastricht-Belvédère. - Mededelingen Rijks Geologische Dienst, 39 (1): 31-34; Maastricht.

- Múcher, H. J., Ouwerkerk, G., Romein, A. \& STOLTENBerG, H. (1983): Evidence for the presence of the Eltville tuff layer in Dutch and Belgian Limbourg and the consequences for the loess stratigraphy. - Eiszeitalter und Gegenwart, 33: 59-78; Hannover.

- \& GroenendijK, A. J. (1999): Midden-Paleolitische vondst in een nieuwe geologische context. - Archeologie in Limburg, 79: 1-6; Limburg.

DeMenocal, P. B. (1995): Plio-Pleistocene African climate - Science, 270: 53-59.

Mestdagh, H. \& Haesaerts, P. (1998): The Rocourt Soil: a pedo-stratigraphic marker for the Last Interglacial. - The Eemian Excursion guide 1998, Local sequences, global perspectives: 27-34.

Paulissen, E. (1973): De morfologie en de kwartairstratigrafie van de Maasvallei in Belgisch Limburg. - Verhandelingen van de Koninklijke Academie voor Wetenschappen, Letteren en Schone Kunsten van België 35: 127 p.; Brussels.

- Gullentops, F., Vermeersch, P.M., Geurts, M,-A., Gilot, E., Neer, W. van, Vooren, E. van \& WageMANS, E. (1981): Evolution holocène d'un flanc de vallée sur substrat perméable (Hesbaye sèche, Belgique). - Mém. Inst. Géol. Univ. Louvain, 31: 23-75.

Petit, J. R., Mounier, L., Jouzel, J., Korotkevich, Y. S., Kotlyakov, V. I. \& Lorius, C. (1990): Palaeoclimatological and chronological implications of the Vostok core dust record. - Nature, 343: 56-58; London.

- Jouzel, J., Raynaud, D., Barkov, N. I., Barnot.a, J.M., Basile, I., Benders, M., Chappellaz, J., Davis, M., Delaygue, G., Delmotte, M., Kutlyakuv, V. M., Legrand, M., Lipenkov, V. Y., Lorius, C., PÉPin, L., Ritz, C., Saltzman, E. \& Stievenard, M. (1999): Climate and atmosferic history of the past 420,000 years from the Vostok ice core, Antarctica - Nature, 399: 429-436; London.

Reille, M., Andrieu, V., Beaulieu de, J.-L., Guenet, P. \& Goeury, C. (1998): A long pollen record from Lac du Bouchet, Massif Central, France: for the period ca. 325 to $100 \mathrm{ka} \mathrm{BP}$ (OIS 9c to OIS 5e). Quaternary Science Reviews, 17: 1107-1123; Amsterdam.

SCHirmer, W. (1999): Kaltzeiten und Warmzeiten im Löss - Terrestrische Quartärgeologie, 81-100.

(2000): Eine Klimakurve des Oberpleistozäns aus dem rheinischen Löss - Eiszeitalter und Gegenwart, 50: 25-49; Hannover.

Tzedakis, P. C., Andrieu, V., Beaulieu de, J.-L., Crowhurst, S., Follieri, M., Hooghiemstra, H., Magri, D., Reille, M., Sadori, L., Shackleton, N. J. \& Wijmstra, T. A. (1997): Comparison of terrestrial and marine records of changing climate of the last 500,000 years. - Earth and Planetary Science Letters, 150: 171-176; Amsterdam.

Vandenberghe, J., Zhisheng, A., Nugteren, G., HuAnYU, L. \& VAN Huissteden, K. (1997): New absolute time scale for the Quaternary climate in the Chinese loess region by grain-size analysis. - Geology, 25 (1): 35-38.

Hujzer, B., Mücher, H. \& LaAN, W. (1998): Short climatic oscillations in a western European loess sequence (Kesselt, Belgium). - Journal of Quaternary science, 13 (5): 471-485; Harlow.

Van den haute, P., Vancraeynest, L. \& de Corte, F. (1998): The Late Pleistocene loess deposits and palaeosols of eastern Belgium: new TL age determinations. - Journal of Quaternary science, 13 (5): 487-497; Harlow.

Vanmontfort, B., Vermeersch, P. M., Groenendijk, A. J., Meijs, E. P. M., DE Warrimont, J.-P. \& GulLENTOPS, F. (1998): The Middle Palaeolithic site of Veldwezelt-Hezerwater, Belgian Limbourg. - No- 
tae Praehistoricae, 18: 5-11; Brussels.

Zoller, L., Stremme, H. \& Wagner, G. A. (1988): Thermolumineszenz-Datierung an Löss-Paläobodensequenzen von Nieder-, Mittel- und Oberrhein/ Bundesrepublik Deutschland.- Chemical Geology (Isotope Geoscience Section), 73: 39-62; Amsterdam.

${ }^{1}$ According to recent knowledge, these TL-ages from Ariendorf, Middle Rhine Valley, must be regarded as underestimated, however (personal communication by L. ZÖLLER). This further strengthens the assignment of C-loess to MIS-8. 